\title{
Educational migration from the countries of the Commonwealth of Independent States to the Russian Federation
}

\section{Migración educativa de los países de la Comunidad de Estados Independientes a la Federación de Rusia}

\author{
Luiza Kajumovna Karimova \\ Candidate of Historical Sciences, Associate Professor, Department of Regional Studies and \\ Eurasian Studies, Institute of International Relations, Kazan Federal University
}

ORCID ID: https://orcid.org/0000-0002-0353-8493

\section{Victoria Ravil'evna Sagitova}

Candidate of psychological Sciences, Associate Professor, Department of Altaic studies and Chinese studies, Institute of International relations, Kazan Federal University

ORCID ID: https://orcid.org/0000-0001-7002-4719

\section{Anna Andreevna Kirpichnikova}

$\mathrm{PhD}$ in Philology, senior lecturer, Department of Foreign Languages, Institute of International

Relations, Kazan Federal University

ORCID ID: https://orcid.org/0000-0003-4261-8004

\section{Ha Van Hoang}

PhD, Faculty of Psychology and Education, The University of Danang - University of Science and Education, Danang, Vietnam

ORCID ID: https://orcid.org/0000-0002-2964-5879

Received 09-08-20 Revised 10-10-20

* Correspondence

Email:LU_KA_S@rambler.ru
Accepted 20-12-21 On line 02-17-21

\section{Citation:}

Luiza Kajumovna Karimova, Victoria Ravil'evna Sagitova, Anna Andreevna Kirpichnikova, Ha Van Hoang (2021). Educational migration from the countries of the Commonwealth of Independent States to the Russian Federation. Propósitos y Representaciones, 9(SPE2), e583. http://dx.doi.org/10.20511/pyr2021.v9nSPE2.1007 


\section{Summary}

Nowadays educational migration is still one of the most relevant topics for Russian and foreign scientists and understudied topic at the same time. Despite the many published sources including quantitative and qualitative aspects of the process, the set of topics under consideration is quite limited (adaptation of foreign students, brain drain, demographical characteristics of migrants, etc.). The article using scientific principles of systematicity and general scientific methods (analysis, synthesis, induction, deduction, comparison, classification, etc.) considers the dynamics of the changes in the amount of foreign students from the countries of the Commonwealth of Independent States to the Russian Federation (including which countries they are from), correlation of the process with forming-up Common Education Space in Russia and CIS. The study conducted led to the conclusion that the actions by government agencies of the Russian Federation, higher education institutions and scientific organizations allowed stopping the negative process of foreign students drain, which took place in 1990-s, promoting and increasing the educational migrant influx from the countries of the Commonwealth of Independent States from 2000 to 2007. Among the leaders in the number of students studying at Russian universities, in early 1990-s there were Kazakhstan, Ukraine and Belorussia and in 2017 there were Kazakhstan, Turkmenistan and Uzbekistan.

Keywords: educational migration, the Russian Federation, the Commonwealth of Independent States

\section{Resumen}

Hoy en día, la migración educativa sigue siendo uno de los temas más relevantes para los científicos rusos y extranjeros y, al mismo tiempo, un tema poco estudiado. A pesar de las numerosas fuentes publicadas que incluyen aspectos cuantitativos y cualitativos del proceso, el conjunto de temas en consideración es bastante limitado (adaptación de estudiantes extranjeros, fuga de cerebros, características demográficas de los migrantes, etc.). El artículo que utiliza principios científicos de sistematización y métodos científicos generales (análisis, síntesis, inducción, deducción, comparación, clasificación, etc.) considera la dinámica de los cambios en la cantidad de estudiantes extranjeros de los países de la Comunidad de Estados Independientes a la Federación de Rusia (incluidos de qué países son), correlación del proceso con la formación del Espacio Común de Educación en Rusia y la CEI. El estudio realizado llevó a la conclusión de que las acciones de los organismos gubernamentales de la Federación de Rusia, instituciones de educación superior y organizaciones científicas permitieron detener el proceso negativo de fuga de estudiantes extranjeros, que tuvo lugar en la década de 1990, promoviendo e incrementando la afluencia de migrantes educativos los países de la Comunidad de Estados Independientes de 2000 a 2007. Entre los líderes en el número de estudiantes que estudian en universidades rusas, a principios de la década de 1990 estaban Kazajstán, Ucrania y Bielorrusia y en 2017 Kazajstán, Turkmenistán y Uzbekistán.

Palabras clave: migración educativa, Federación de Rusia, Comunidad de Estados Independientes.

\section{Introduction}

Nowadays educational environment is a great scope for the development of the relations between Russia and countries of the Commonwealth of Independent States. In May 1992 the leaders of CIS countries signed the Agreement on collaboration in the sphere of education and enacted provision for Conference of ministers of education of member states (https://e-cis.info). Then, in January 1997, the Conception of forming-up Common Education Space in CIS countries and Agreement on collaboration in the sphere of forming-up Common Education Space in CIS were signed (http://www.russia.edu.ru). In 2001, several laws of Interparliamentary Assembly about formingup legal framework for all-round cooperation in the sphere of education were passed (https://iacis.ru/). 
During the period from 2000 to 2011, twelve universities were chosen and they gained status of base organizations (regard with cooperation in the sphere of education). The first university, which gained this status, was Moscow State Linguistic University (decision by Council of State Leaders, 30th November 2000, Minsk) (http://old.e-cis.info). Then another universities gained status of base organizations such as Lomonosov Moscow State University (MGU), Saint Petersburg State University, Peoples' Friendship University of Russia, State Technological University "Moscow State Institute of Steel And Alloys", etc.

The main goal of the base organizations is forming-up Common Education Space, elaboration and realization of the plan of activities approved by Council of State Leaders, work on organization of council boards, conferences, seminars and exhibitions. The Institute for Adult Education of Russian Academy of Sciences being a base organization regard with issues of adult education and educational activities elaborated a project of The Conception of adult education development in the CIS countries and Activity Plan for its realization approved by Council of State Leaders (http://www.russia.edu.ru). The base organizations also elaborated a plan for widening distance learning technologies usage for CIS members (https://e-cis.info).

In 1998, Conference of ministers of education of member states of the Commonwealth of Independent States (CIS) renewed its activity. Since then Conference has considered some important issues on development of collaboration in the sphere of education and made some decisions on them, including some documents on criteria and monitoring technologies, quality of education, academic degrees and ranks, monitoring technologies of education quality control, a model of educational standard of higher (professional) education (in the field of study), passports of scientific specialties elaborated by State Commission for Academic Degrees and Titles of the Russian Federation and Nomenclature of specialties of scientific workers of the Russian Federation were approved as basic (Ovezova \& Wagner, 2012).

\section{Methods}

The methodological base of the research includes as general scientific methods of analysis and synthesis, induction and deduction, comparison and classification, etc., as applied statistic methods in order to aggregate quantitative data on educational migration from countries of the Commonwealth of Independent States to the Russian Federation.

Moreover, scientific principles of systematicity and historicism as well as nuanced approach to the problems under investigation were used. In the frame of systematic approach international relations development of Russia and CIS countries was considered through educational migration processes and as single complex system, all elements of which are interconnected. Analysis of the system suppose the use of the principle of historicism, which allows us to consider tendencies, which are interesting for us, in process and in connection with factors which bring about this dynamics.

\section{Results and Discussion}

Forming up legal framework and creation of base organizations in the frame of Common Education Space in the countries of Commonwealth of Independent States activated educational migration processes providing development of international relations of CIS countries.

Educational migration processes are interesting for contemporary scientists. However, despite the great amount of source materials on the topic including qualitative and quantitative aspects of the process the range of topics considered by researchers is limited (internationalization of education, adaptation of foreign students, demographic characteristics of migrants, etc.) (https://fgos.ru).

During the first years of Common Education Space forming up the amount of students from CIS countries, who studied at Public higher education institutions of Russia, decreased 
dramatically from 103.9 thousand people in 1992 to 34.4 thousand people in 2000 . The most dramatic decrease was in the period from 1992 to 1995 - more than 2.5 times (to 39.8 thousand people). The reduction in number of foreign students from CIS countries stopped only in 1998 (when it was 28.5 thousand people), then there was slow growth (Cobb-Clark et al., 2019).

In 1992 the top sending countries of foreign students to Russian universities were Ukraine (29.9 thousand people, $28.8 \%$ of total amount of foreign students from CIS countries who studied at Russian universities), Kazakhstan (22.0 thousand people or 21.2\%), Georgia (11.4 thousand people or 11.0\%) (Cobb-Clark et al., 2019). They were followed by Belarus, Uzbekistan, Azerbaijan, Armenia, Kyrgyzstan, Tajikistan, Moldova, Turkmenistan in decreasing order.

Only one year after, among leaders, there were Kazakhstan (11.6 thousand people or 29.1 $\%$ ), Ukraine (9.5 thousand people or $23.9 \%$ ), Belarus (4.4 thousand people or $11.1 \%)$. These countries managed to keep leading position until 2000: Kazakhstan (16.7 thousand people or $48.5 \%$ ), Ukraine (5.0 thousand people or $14.5 \%$ ), Belarus (3.4 thousand people or 9.9\%) (CobbClark et al., 2019). In 2000, they were followed by Uzbekistan, Azerbaijan, Kyrgyzstan, Armenia, Moldova, Georgia, Turkmenistan, Tajikistan.

Increase in the number of foreign students in Russia in general and from CIS countries in particular was in 2000-2008. Thus, if in the beginning of 2000-2001 academic year there were 34.4 thousand foreign students from CIS countries, in the beginning of 2010-2011 academic year there were 73.1 thousand people (exclusive of Georgia which withdrew from membership of CIS in August 2009), in 2015-2016 academic year - 124.0 thousand people, in 2017-2018 academic year - 145.2 thousand people (Fayzullina, 2012).

There was a stable growth of the amount of foreign students from such countries as Kazakhstan (52.7 thousand people in the beginning of 2017-2018 academic year), Turkmenistan (20.4 thousand people), Uzbekistan (20.3 thousand people), Tajikistan (14.3 thousand people), and Kyrgyzstan (5.5 thousand people). As to top countries, in 2010-2011 academic year they were Belarus, Kazakhstan, Azerbaijan, following years Kazakhstan managed to keep leading position, the second and the third positions were given to Uzbekistan and Turkmenistan although the latest always increased the temps of growth and became able to take the second position by the beginning of 2017-2018 academic year (Fayzullina, 2012).

From 2010-2011 academic year to 2017-2018 academic year the amount of foreign students at universities and scientific organizations in Russia increased from 153.8 thousand people to 260.1 thousand people. During this period the number of foreigners who enrolled at universities and scientific organizations increased as well although the proportion of foreigners who graduated from Russian universities and scientific organizations decreased from 24.1 thousand people (64.6\%) to 41.1 (47.7\%) (Fayzullina, 2012).

From 2010-2011 academic year to 2017-2018 academic year, the number of people from CIS and Baltic countries and Georgia who were admitted to Russian universities increased from 27.9 thousand to 60.3 thousand, at the same time the proportion of foreign students who were admitted to Russian universities vice versa decreased from $74.8 \%$ to $70.1 \%$. The proportion of foreign graduates from CIS and Baltic countries and Georgia of total amount of graduates dropped from $56.6 \%$ to $39.8 \%$, at the same time absolute measures increased from 15.8 thousand people in 2010 to 24.0 thousand people in 2017. In 2010-2017, total amount of students from CIS and Baltic countries and Georgia at Russian universities and scientific organizations increased from 116.7 thousand people (75,9\% of total amount of foreign students) to 191.6 thousand people $(73,7 \%)$ (Fayzullina, 2012; Forbes-Mewett \& Nyland, 2008).

\section{Summary}

Given data proves about special policy forming-up in 1990-s in order to attract foreign students to Russian universities. It produced an effect in the beginning of 2000-s when the gradual increase in the number of students from CIS countries began. 
It was caused by several factors. Policy of forming-up Common Education Space in Russia is built up in the frame of the Conception of national policy in the sphere of local labor training for foreign countries at Russian educational institutions (Perrucci \& $\mathrm{Hu}$, 1995). The Russian Federation has top course focused on development of integration in the Commonwealth of Independent States via the local labor training as a part of international economic activity. Moreover, using educational migration as "soft power" in the territory of CIS members Russia can deliver on geopolitical and social-economic interests in their territory by the means of high-quality training and competitive ability of graduates from educational institutions on the world market of education and labor (Schneeweis, 2008; Shakirova, 2019; Shakirova \& Gizyatova, 2018; Zhou et al., 2008; Russian Statistical Yearbook 2003 [Electronic resource]).

In the frame of the Conception long-term economic and political interests of Russia will be delivered on by the means of strength in Russian position as the main educational center; realization of the principle of people's equality in education not only for the Russian but for foreigners as well; widening of the Russian language and culture study abroad; widening of opportunities of scholarship programs realization for training, retraining of specialists and advanced training of academic staff and other professionals as for contributing countries as for companies which are set up abroad with contributions from the Russian Federation; development of the system of academic recognition for diplomas of Russian universities in CIS members; adaptation of Russian educational programs and institutions to work on the world market of education via studying experience of academic credits system; state system development for management of not only learning services quality but also for following realization of knowledge people got at Russian universities on the territory of CIS members; opening branches of educational organizations on the territory of CIS members and forming-up legal framework for admission, study and graduation of foreign citizens; development of security arrangements for foreign students, their health protection on the territory of the Russian Federation; programs development on damage prevention to Russia's national security while delivering learning service to foreign citizens.

Dynamics of the amount of foreign students from CIS members proves efficiency of the strategy chosen.

\section{Conclusions}

In regard to educational migration from CIS countries to the Russian Federation by the beginning of 2000-s it became possible to reverse the downward spiral of the reduction in the number of foreign students and by 2017-2018 academic year one managed to increase the rate of growth in this category of students at universities and scientific organizations. Among top countries sending students to Russian universities, in the beginning of 1990-s there were Kazakhstan, Ukraine and Belarus, by the beginning of 2017-2018 academic year - Kazakhstan, Turkmenistan, Uzbekistan.

\section{Acknowledgements}

The work is performed according to the Russian Government Program of Competitive Growth of Kazan Federal University.

\section{References}

Action Plan for the Implementation of the Concept for the Development of Adult Education in the CIS Member States [Electronic resource] - URL: http://www.russia.edu.ru/information/legal/law/inter/proekt/sng/2804/ (accessed: 13.04. 2020).

Agreement on cooperation on the formation of a single (common) educational space of the CIS [Electronic resource] - URL: http://www.russia.edu.ru/information/legal/law/inter/cng/17 01_1997/ (d accessed: 20.05 $.2020)$ 
An interaction plan to expand the use of distance learning technologies will be considered at the upcoming meeting of the CIS Council of Heads of Government / INTERNET PORTAL CIS [Electronic resource] - URL: https://e-cis.info/page/3435/80103/ (accessed: 13.04. 2020).

Belov, V.A. (2004). Improving the organization of the apparatus for training foreign citizens in Russia at the present stage. HRUDN, Ser. Jurisprudence, 1, 71-82.

Cobb-Clark, D.A., Sinning, M., \& Stillman, S. (2019). Migrant's youth/s educational achievements: the role of institutions. In: The Annals of the American Academy of Political and Social Science, 29 p.; 3.

Decision on granting Moscow State Linguistic University the status of a basic organization for the languages and culture of member states of the Commonwealth of Independent States - CIS Internet portal [Electronic resource] - URL: http://old.e-cis.info/page.php?id=21360 (accessed: 20.05. 2020).

Fayzullina, O.R. (2012). Ways of international students' adaptation: Club of international friendship. Space and Culture, India, 6(5), 87-98.

Forbes-Mewett, H., \& Nyland, C. (2008). Cultural diversity, and the security of international students at an Internationalized University. Journal of Studies in International Education, 12(2), 181-203.

Foreign students studying undergraduate, specialty, master's programs in higher education and scientific organizations of Russia. Russian Statistical Yearbook. 2018. [Electronic resource] - URL: https://www.gks.ru/bgd/regl/b18 13/Main.htm (accessed: 20.05.2020)

Layout of the educational standard of higher (professional) education (in the direction / specialty) of the states [Electronic resource] - URL: https://fgos.ru/ (accessed: 13.04. 2020); Order of February 25, $2009 \mathrm{~N} 59$ "On approval of the Nomenclature of scientific specialties for which academic degrees are awarded" (as amended on June 8, 2017) [Electronic resource] - URL: http://docs.cntd.ru/document/902148629 (accessed: 13.04. 2020); Order of the Ministry of Education and Science of the Russian Federation dated February 25, 2009 No. 59 "On Approving the Nomenclature of Specialties of Scientific Workers" [Electronic resource] - URL: https://www.garant.ru/products/ipo/prime/doc/95207/ (accessed: 13.04. 2020).

Model Codes and Laws / Documents of the IPA CIS / Inter-Parliamentary Assembly of the Member States of the Commonwealth of Independent States [Electronic resource] - URL: https://iacis.ru/activities/documents/?category $=80$ (accessed: 20.05. 2020) .

Ovezova, W.A., \& Wagner, M.-N.L. (2012). Cooperation of the CIS countries and Russia in the field of education. Theory and practice of social development, 11, 181 -183.

Perrucci, R., \& Hu, H. (1995). Satisfaction with social and educational experience among international graduate students. Research in Higher Education, 36(4), 491-499.

Regulation on the Conference of Ministers of Education (and Science) of the States [Electronic resource] - URL: https://e-cis.info/cooperation/2854/77318/ (accessed: 20.05. 2020)

Schneeweis, N. (2008). Education institutions and integration of migrants. Journal of Population Economics, 24, 1281-1308.

Shakirova, A. (2019). Internationalization of higher pedagogical education. ARPHA Proceedings, $1,613-619$.

Shakirova, A.A., \& Gizyatova, L.A. (2018). Forms of Students' Academic Mobility Organization in Russian Universities. ORBIS, 14, 65-73.

The concept of the state policy of the Russian Federation in the field of training national personnel for foreign countries in Russian educational institutions. [Electronic resource] - URL: http://docs.cntd.ru/document/901857022 (accessed: 20.05. 2020)

The number of students from CIS countries who studied undergraduate, specialty, master's programs in state and municipal educational institutions of higher education and scientific organizations of Russia on a general admission basis. Russian Statistical Yearbook. 2018. [Electronic resource] - URL: https://www.gks.ru/bgd/regl/b18_13/Main.htm (accessed: 20.05.2020)

The number of students from the CIS countries studying at state higher educational institutions of Russia. Russian Statistical Yearbook 2003 [Electronic resource] - URL: https://www.gks.ru/bgd/reg1/b03 13/IssWWW.exe /Stg/d020/i020230r.htm (accessed: 20.05.2020) 
Zhou, Y., Jindal-Snape, Topping, K., \& Todman, J. (2008). Theoretical models of culture shock and adaptation in international students in higher education. Studies in Higher Education, $33,63-75$. 